\title{
Impact of Flood on the Socio-Economic Conditions in the Southern Part of Kamrup District, Assam
}

Dr. Indira Das ${ }^{\dagger *}$ and Dr. Sujit Deka

\section{Abstract}

Flood causes extreme loss of infrastructure and human life; besides it also propagates the condition of poverty and unceasing marginalisation of the affected region from development. This study elucidates how flood contributes to the socio-economic conditions of the rural people living in the Southern part of the Kamrup district of Assam. It focusses on flood hazard zoning and flood vulnerability analyses that are delineated based on the data collected from the Moderate Resolution Imaging Spectroradiometer (MODIS) Near Real-Time (NRT) Global Flood Mapping Product Portal. Flood hazard zoning of the study area is done using Multi-Criteria evaluation method based on rainfall distribution, slope, drainage density, population density, soil type, elevation, flow accumulation, roads and embankment utilising Cartosat DEM and IRS P6 LISS III data. The zones are identified as actively flooded, chronically flooded and occasionally flooded zones, which affects 39.4 per cent, 12.9 per cent and 26.1 per cent population respectively covering $1189.2 \mathrm{sq} . \mathrm{km}$, that is, $\mathbf{5 6 . 5}$ per cent area of the study region. The flood vulnerability assessment of the study area is done at village and ward level adapting geospatial assessment in a GIS environment. The findings of the research are generated through observations, key informant interviews with the rural population surveying 1420 number of households. It reveals that 200 villages are affected by floods every year that constitutes 76.6 per cent households and 78.4 per cent of the population of the study area.

Keywords: Floods; Flood Hazard Zones; Vulnerability Assessment; GIS; Thematic Maps; Kamrup District; Assam; India

\footnotetext{
${ }^{\dagger}$ Research Scholar, Department of Geography, Gauhati University, Assam, India

${ }^{*}$ Corresponding Author, Email: indirachh@gmail.com

I Professor and Head,Department of Geography,Bodoland University, Bodoland Territorial Council, Assam, India, Email: sujitdeka@gmail.com

(C) 2021 Das \& Deka. This is an Open Access article distributed under the terms of the Creative Commons Attribution License (http://creativecommons.org/licenses/by/2.0), which permits unrestricted use, distribution, and reproduction in any medium, provided the original work is properly cited.
} 


\section{Introduction}

Complete protection from floods is unachievable and unattainable, but the supplementary riverfriendly and a reduced number of interfering methods are essential to attain sustainable flood management (Singh \& Kumar, 2017). This study is mainly aspired towards evaluating the impact of the flood on the southern part of Kamrup District. Here the focus is on flood hazard mapping along with an assessment of flood hazard vulnerability for future planning and management of socio-economic loss in the study area. It is comprehended that populations with insufficient societal, financial, and governmental sources often disproportionately inhabit the riskiest environmental parts, resulting in the most significant physical impacts such as casualties and property loss during a disaster (Morrow, 2008). The vulnerability to women's flooding risk intensifies as their earningare minimal and also because they are bound by their responsibilities as caretakers of their children and elderly people of the family (Schmidtlein et al., 2008). Flood nature that is, frequency, interval, and depth and the form of vulnerability of a region govern the extent and degree of flood devastation in an area (Birkmann, 2006). In this study, we have applied Remote Sensing and Geographical Information System (GIS) to map and analyse flood hazard zones and flood vulnerable areas. The findings reveal that 200 villages are affected by floods, and 21.3 per cent of households, 18.2 per cent of the population, 21.2 per cent of females and 19.9 per cent of children and 21.9 per cent of primary workers are highly vulnerable to flood hazards.

Assam, which is in the monsoon climatic region; has been experiencing an average annual rainfall between $1600 \mathrm{~mm}$ and $4300 \mathrm{~mm}$ enduring the cause of flood in the entire area (Assam State Disaster Management, n.d.). Due to the orographic situation of the Mishmi Hills, Abor Hills, and the Dafla hills in the Himalayan region of Arunachal Pradesh, and Khasi-Jaintia Hills in Meghalaya that causes the moisture-laden monsoonal winds to shed their moisture on the hilly terrain (Dhar \& Nandargi, 2004). The overflowing of he Brahmaputra river's tributaries also adds to the volume of floodwater in the valley (Sharma et al., 2012). Moreover, the state has a specific hydrological, meteorological and unstable geological condition, which magnifies the root for various geomorphic and geological hazards in the region. This is intensified by the recurrent episodes of earthquakes which often triggers landslides in the neighbouring hills disrupting the normal flow of the tributaries of river Brahmaputra basin (Mirza et al., 2001) The region experienced massive floods during the year 1954, 1962, 1972, 1977, 1984, 1988, 1998, 2002, 2004, 2012 and 2017. The total geographical area of Assam impacted by flood is assessed to be about 2.221 million hectares of land, indicating about 28.31 per cent area (Sharma et al., 2012). The flood damaged about 1.495 million hectares of cropped area during 1998-2007 (Sharma et al., 2012). According to the Department of Water Resources, Government of Assam, India, 48.27 million hectares of land were eroded, and 119.2 million people were affected by bank erosion from 2001 to 2006 (n.d.). Sarma (2005) noted that the average bank-line shift of the north bank of the Brahmaputra towards the north is estimated to be $227.5 \mathrm{~m} /$ year on an average and $137.2 \mathrm{~m} /$ year towards the south (p. 223). The southern part of Kamrup district is mostly a lowlying undulating region drained by the southbank tributaries of the Brahmaputra river namely Kulsi, Boko, Singra and Singhua. These rivers are flashy and known to people of this region for bed aggradation. The monsoonal rain contributes around 82 per cent of the Brahmaputra's mean annual flow at Pandu which is the upstream region of the study area (Goswami, 1985). Therefore, it is realised that flood risk will not decrease in the future; instead, the impact is likely to increase in the study area.

\section{Objectives}

The study is sought to appraise the impact of the flood on the socio-economic conditions of the area. Thus, three objectives were considered 
- To prepare a flood hazard zonation map which is a cost and time-effective way to mark out the active, chronically and occasionally flooded area.

- To survey flood-affected villages based on the flood hazard zonation map to assess the impact of flood.

- To identify flood vulnerable areas based on flood hazard zonation as high, moderate and low vulnerable areas.
The study area lies on the southern bank of the mighty Brahmaputra, stretching from Palasbari to Nagarbera as illustrated in Figure 1. According to the Ministry of Home Affairs (2011), it covers $2,101.8 \mathrm{sq}$. $\mathrm{Km}$. with a total population of 810094, 649 revenue villages and 17 semi-urban towns. The National Highway 37 crosses through the area and is drained by rivers Brahmaputra, Kulsi, Boko, Singra and Singua and their tributaries.

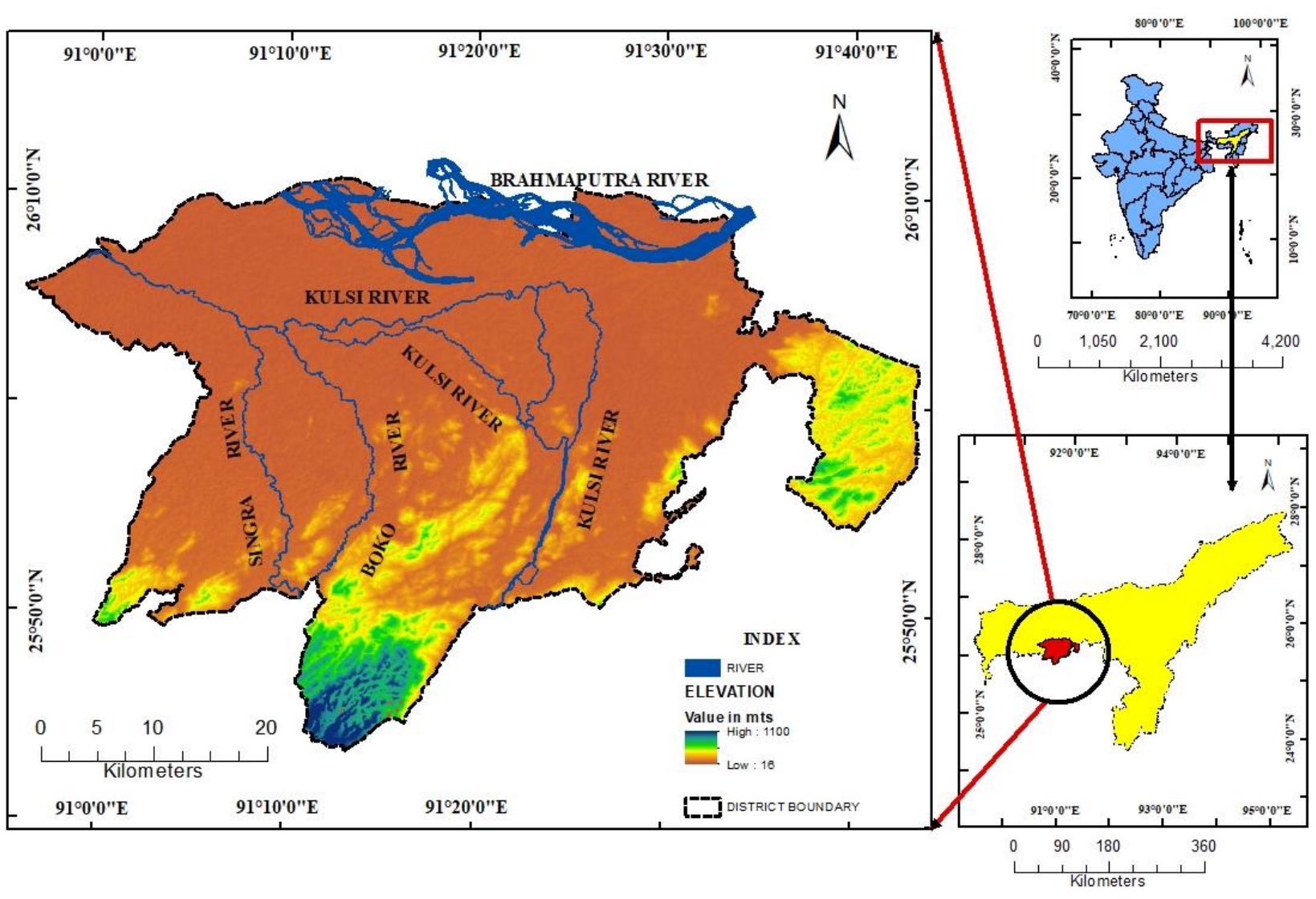

Figure 1: Location Map

Source: Authors

\section{Methodology}

In the study area, flood is identified as active flood area (inundated every year), chronically flooded area (inundated every five years) and occasionally flooded area (less than five years). Flood in the study area deduced from the flood inundation map prepared in GIS environment has unveiled the extent of flood occurrence. The flood-affected areas are demarcated from the annual flood layers of 1999, 2004 and 2010, accessed from the Bhuvan Indian Geo-Platform of ISRO. The 14 days composite flood inundation in August for the years 2013, 2014, 2015, 2016 and 2017 are accessed from Moderate Resolution Imaging Spectroradiometer (MODIS) Near Real-Time (NRT) Global Flood Mapping Product Portal (MODIS, 2017). The flood inundated areas are digitised manually in Arc GIS 10 software whereas shapefile (.zip) and $\mathrm{KMZ}$ files are obtained from MODIS inundation data. The flood hazard zonation map (Figure 3) are developed based on the thematic maps of rainfall distribution, slope, drainage density, population density, soil type, elevation, flow accumulation, roads and embankment. These 
are prepared using the Equal Interval Method in Arc GIS software by assigning a weight to each class. The survey of India Topographic maps of scale 1:50000, Cartosat DEM and IRS P6 LISS III data of 16 February 2016, are used for MultiCriteria evaluation, and a personal database is created in Arc Catalog with the spatial reference of GCS_WGS_1984. After digitising and plotting the maps, each factor's ranks are given based on its estimated significance in causing the flood. The data layers are finally integrated into the GIS environment by weighted overlay analysis using the Raster calculator tool. To minimise the effect of the river bank inundation, a flood vulnerability map for the area is prepared (Figure 4), taking

\section{$\mathrm{SEV}=\mathrm{SEV} 1+\mathrm{SEV} 2+\mathrm{SEV} 3$}

Where, SEV denoted Socio-economic Vulnerability and SEV1, 2, 3...6 are standardised into account the socio-economic and physical factors. The vulnerable areas are categorised by the inhabited region that is socio-economically miserable and susceptible to flood. Thus, the demographic section's vulnerability is obtained by computing the average socio-economic vulnerability normalised between 0 and 1 , based on particular socio-economic indicators. The flood exposure vulnerability is considered focused on the flood zonation of the area. A combined value of socio-economic vulnerability of the area is computed as the average of normalised indicator values using the following equation:

\section{SEV3+.........SEV6/ 6}

Flood vulnerability of the study area is done based on the socio-economic data (Ministry of Home Affairs, 2011) of village and ward level and integrated into a GIS format for geospatial evaluation. The various socioeconomic factors like total population, female population, children, total households, literacy, total working population and the parameters of the flood are evaluated using the geospatial technique. The weights have been given on priority basis assigning high-risk category with more pressure. After execution of the multi-criteria overlay approach to these indicators in the GIS environment, three classes of vulnerability that is low, moderate and high vulnerability classes are found.

\section{Findings}

The present-day increasing population and their widespread varying commercial undertakings in the flood plain has resulted in recurrent floods with greater intensity and risk (Hazarika, 2016). However, the hydrological regime of the mighty river Brahmaputra, along with the rivers Kulsi,

\section{tors as presented in Table 1.}

Boko, Singra, Singua and their tributaries are the primary sources of floods in the study area. The findings suggest that floods are rampant in Palasbari, Goroimari, Chamaria, Nagarbera and parts of Boko revenue circles. From the flood zonation map; it is found that in the study area, more than 200 villages are affected by floods every year. Twenty-two villages are randomly selected from the study area, and the magnitudes of the effect of the flood are recorded through personal and household interviews with a prepared questionnaire. The names of these villages are Pujupara, Nagarbera, Badla Pathar, Malibari Pathar No.2, Tamuldi, Laruajan, Puran Kuchia, Achal Para Baghamara, Sikhaharthi, Satpakhola, Kalahi Kakh, No.2 Uttar Rangapani, Howlitari, Neul Dova, Champupara Gaon, Majkuchi, Sathikopra, Noiter Khola, No.1 Barua Pathar, Pach Gumi, Tapar Pathar and Rampur No.1. It has been calculated that the total area inundated during 2015, 2016 and 2017 based on MODIS flood inundation maps are 58.5 sq. Km, 206.8 sq. $\mathrm{Km}$ and $201.6 \mathrm{sq}$. $\mathrm{Km}$ respectively. 


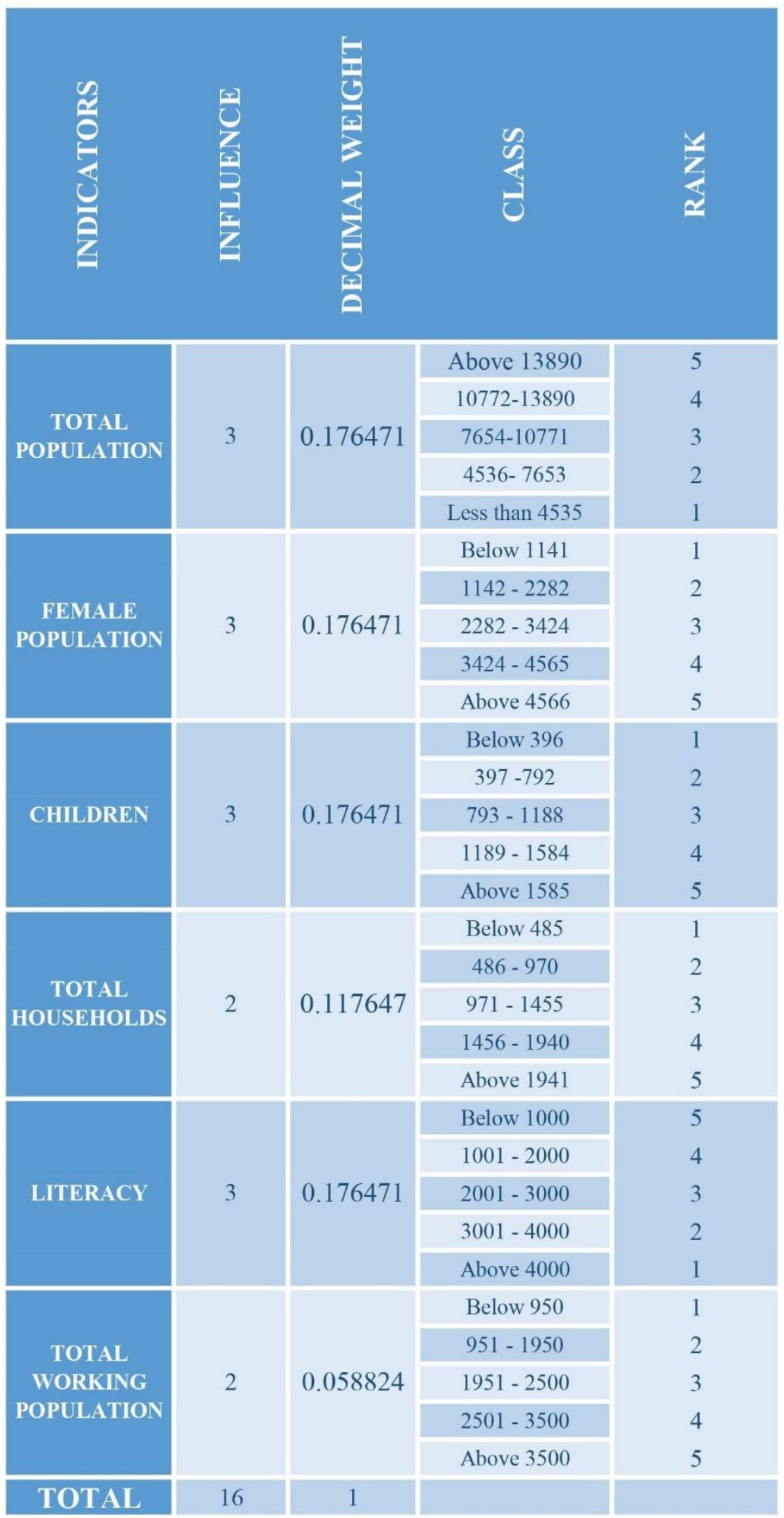

Table 1: Socio-Economic Indicators of Flood Vulnerability Source: Calculation by the Authors based on the Socio-Economic Data, Ministry of Home Affairs, 2011 
The derived flood zonation map (Figure 2) and region, 76.6 per cent of households are affected the percentage of area under flood as given in by the flood. Thus, it is apparent that the Table 2 is used to validate the flood-prone fields. surveyed villages are severely affected by the As is evident from Table 1, the total flood-prone floods.
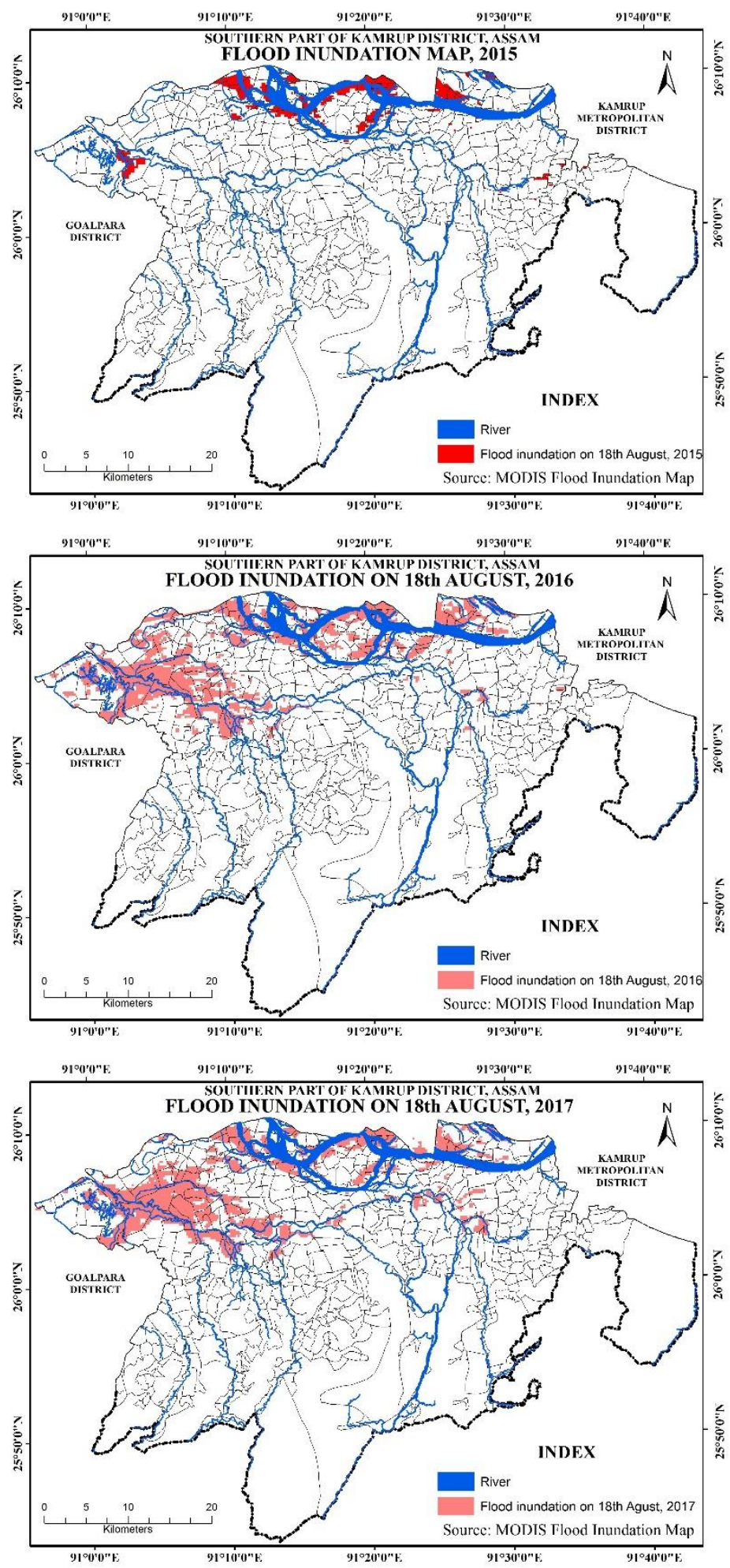

Figure 2: Flood inundation Map of 2015, 2016 and 2017 Source: MODIS near Real-Time (NRT) Global Flood Mapping Product Portal 


\begin{tabular}{|c|c|c|c|c|c|c|c|c|c|c|c|}
\hline 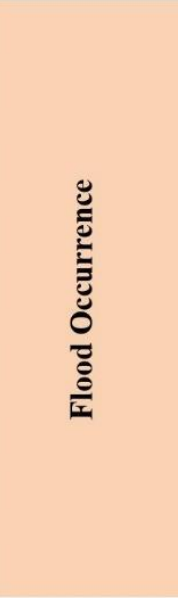 & 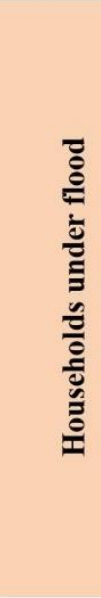 & 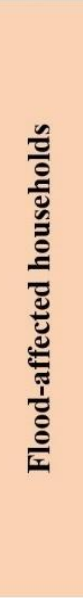 & 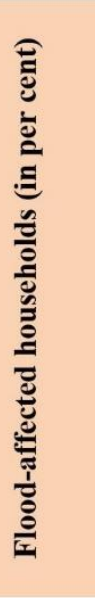 & 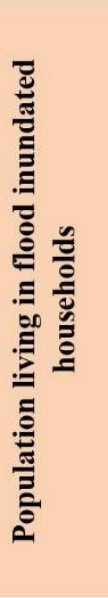 & 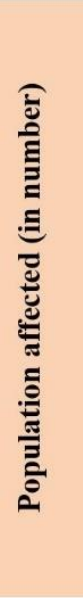 & 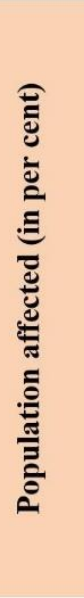 & 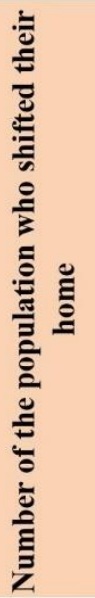 & 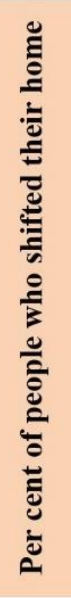 & 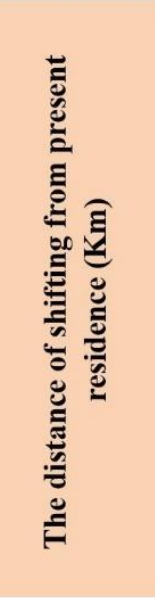 & 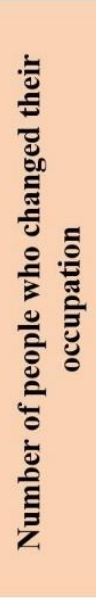 & 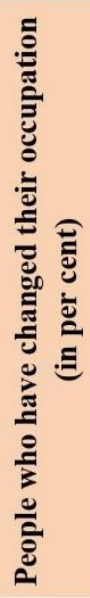 \\
\hline Active & 668 & 564 & 39.7 & 3797 & 3109 & 39.4 & 142 & 2.9 & 5-Feb & 92 & 1.9 \\
\hline Chronically & 170 & 170 & 11.9 & 1062 & 1024 & 12.9 & 29 & 1.64 & 2-Jan & 27 & 1.5 \\
\hline Occasionally & 580 & 354 & 24.9 & 3022 & 2058 & 26.1 & 2 & 0.2 & Less than 1 & 0 & 0 \\
\hline Total & 1420 & 1088 & 76.6 & 7881 & 6191 & 78.5 & 173 & 2.2 & & 119 & 1.51 \\
\hline
\end{tabular}

Table 2: Occurrence of Flood and their Impact on the Socio-economic Life of the Study Area Source: Field Survey carried out During November 2015, March to November of 2017

The entire floodplain can be categorically demarcated into the following classes:

\section{Active Flood Occurrence Area}

The factors of flood hazard in this zone may be because of extreme low altitude, very gentle slope, proximity to the river Brahmaputra and Kulsi, around $1416 \mathrm{~mm}$ annual rainfall and around 1332 persons per sq. Km high population density (Das, 2020). Out of the total, 39.7 per cent of households are affected by flood. Moreover, out of the total population living in flood inundated areas, it is found that 39.4 per cent of the population are affected. The data reveals that 142 people permanently shifted to a distance of 2 to $5 \mathrm{~km}$ from their original residence. It is observed that 43 families from Achalpara Baghamara and Puran Kuchiya villages have shifted to the nearby embankment of the Brahmaputra river. Ninety-two families had to change their occupation due to the flood. These people now mostly earn their living by working in Guwahati as daily wage earners. As shown in Table 3, Pujupara, Nagarbera, Achal Para Baghamara and Satpokhali are the worst affected villages. Amongst them, more than 90 per cent of the population are severely affected. As seen in Table 3, almost 3.90 million hectares of cropland are damaged and thirty-eight cattle lost life in the flood. The depth of flood inundation is found to be varying from 2 to 3 feet with moderate flooding of twenty-five to thirty numbers of days. The average working days lost by the working population is ten to sixteen days. As understood from Table 3, the school days lost by the school children accounted for fourteen to thirty days.

\section{Chronic Flood Occurrence Area}

Low elevation, gentle slope, high density of population and moderate closeness to river Brahmaputra, river Kulsi and river Boko are the factors of occasional occurrence of flood in this zone. However, these areas are susceptible to flood regularly and hence 11.9 per cent households are chronically affected. This zone includes cropland and settlements of lesser stretch of the rivers. In this zone 12.9 per cent population are affected. Neul Dova and Champupara villages are the worst affected. Neul Dova was found to be fully submerged in flood whereas 96.7 per cent of population are affected in Champupara village. Flood water inundated 152 hectares of cropland. The area remained waterlogged for a period of eight to ten days with a depth of 1 to 2 feet during the 
harvest season. As observed from Table 3, the their home and two persons shifted to a distance average working days lost in this area is three to of $2 \mathrm{~km}$. Altogether 27 people had to change nine days. The number of school days dropped their mode of earning. These people have accounted for five to six days. The survey shows become agricultural labourers. that 29 people shifted to a distance of $1 \mathrm{~km}$ from

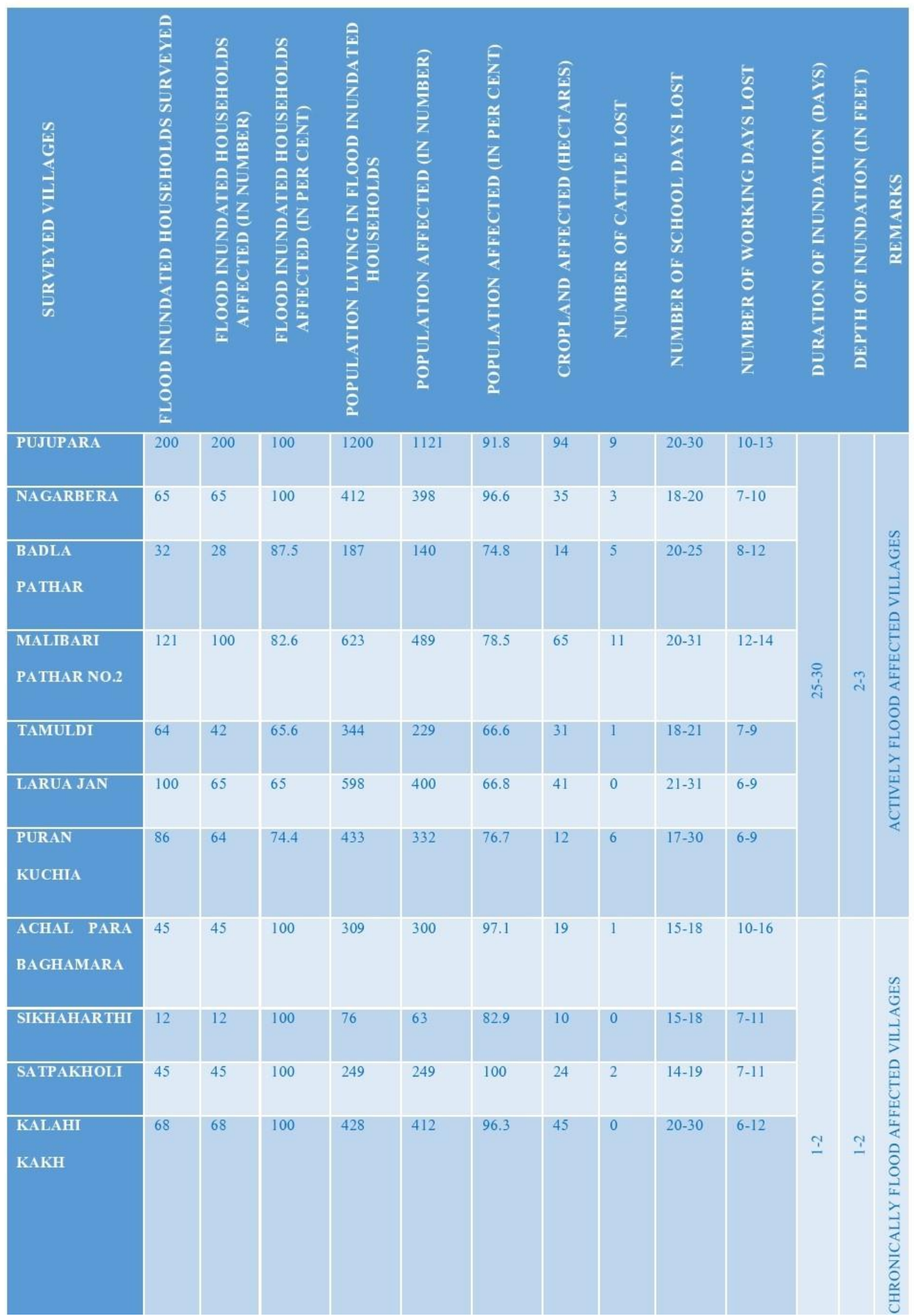




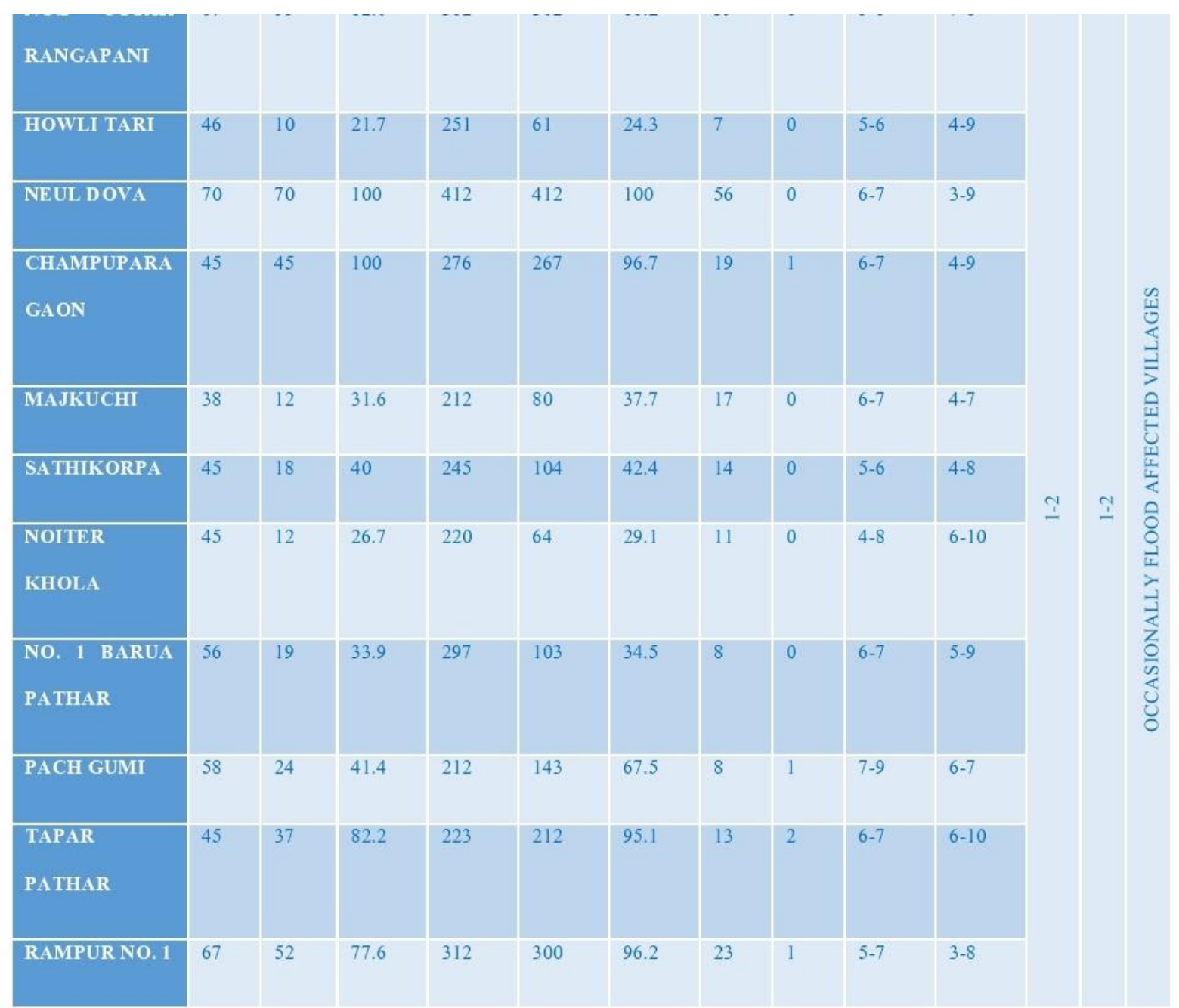

Table 3: Flood Damages in Active, Chronically and Occasionally Flooded Areas

Source: Field Survey Carried Out During November 2015, March to November of 2017

\section{Occasional Flood Occurrence Area}

The magnitude of flood in the occasional flood occurrence area is less as compared to the active and chronically flood occurrence areas as the fields are located at a slightly higher elevation. Rainfall is high in this zone, and the drainage density is moderate, but the flow accumulation is very high, so the water does not remain stagnant here (Das, 2020). Here, 24.9 per cent households and 26.1 per cent population are affected due to floods. However, it was observed that the flood-damaged 65 hectares of cropland here. Tapar Pathar and Rampur No. 1 are the most critically flood-affected villages in the region. These villages include 95.1 per cent and 96.2 per cent of the flood-affected population, respectively. The entire area remained waterlogged during this period for three to four days, maintaining a depth of 1 to 2 feet. So, the working days were restrained to three to ten days, and the number of school days lost is four to nine days.

Subsequently, it was perceived that 56.5 per cent of the entire area is affected by the floods. As shown in Table 4, almost 10.9 per cent area is highly flood-affected, while 37.9 per cent and 7.71 per cent are moderately and less affected by the flood, respectively. 


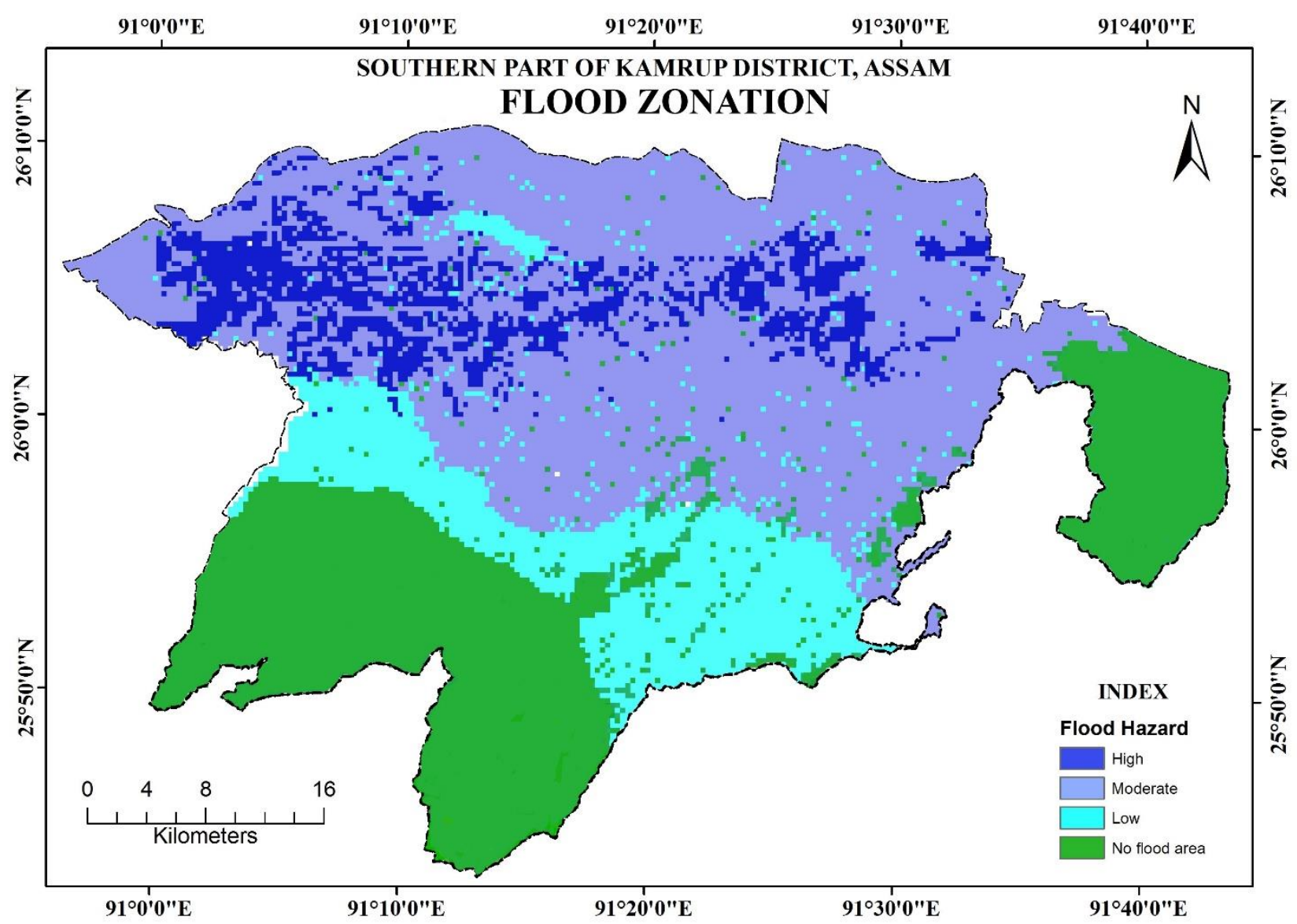

Figure 3: Flood Hazard Zones

Sources: MODIS near Real-Time (NRT) Global Flood Mapping Product Portal and Field Survey Carried out during November 2015, March to November of 2017

\begin{tabular}{|cccc|} 
Sl. No. & $\begin{array}{c}\text { Flood } \\
\text { intensity }\end{array}$ & $\begin{array}{c}\text { Flood } \\
\text { affected area } \\
\left.\mathbf{( K m}^{\mathbf{2}}\right)\end{array}$ & $\begin{array}{c}\text { Flood affected } \\
\text { area (in per } \\
\text { cent) }\end{array}$ \\
\hline 1 & High & 229.3 & 10.9 \\
\hline 2 & Moderate & 797.8 & 37.9 \\
\hline 3 & Low & 162.1 & 7.71 \\
\hline & Total & $\mathbf{1 1 8 9 . 2}$ & $\mathbf{5 6 . 5}$ \\
\hline
\end{tabular}

Table 4: Table Showing Area under Flood Hazard Source: Authors' Calculation based on Field Survey 


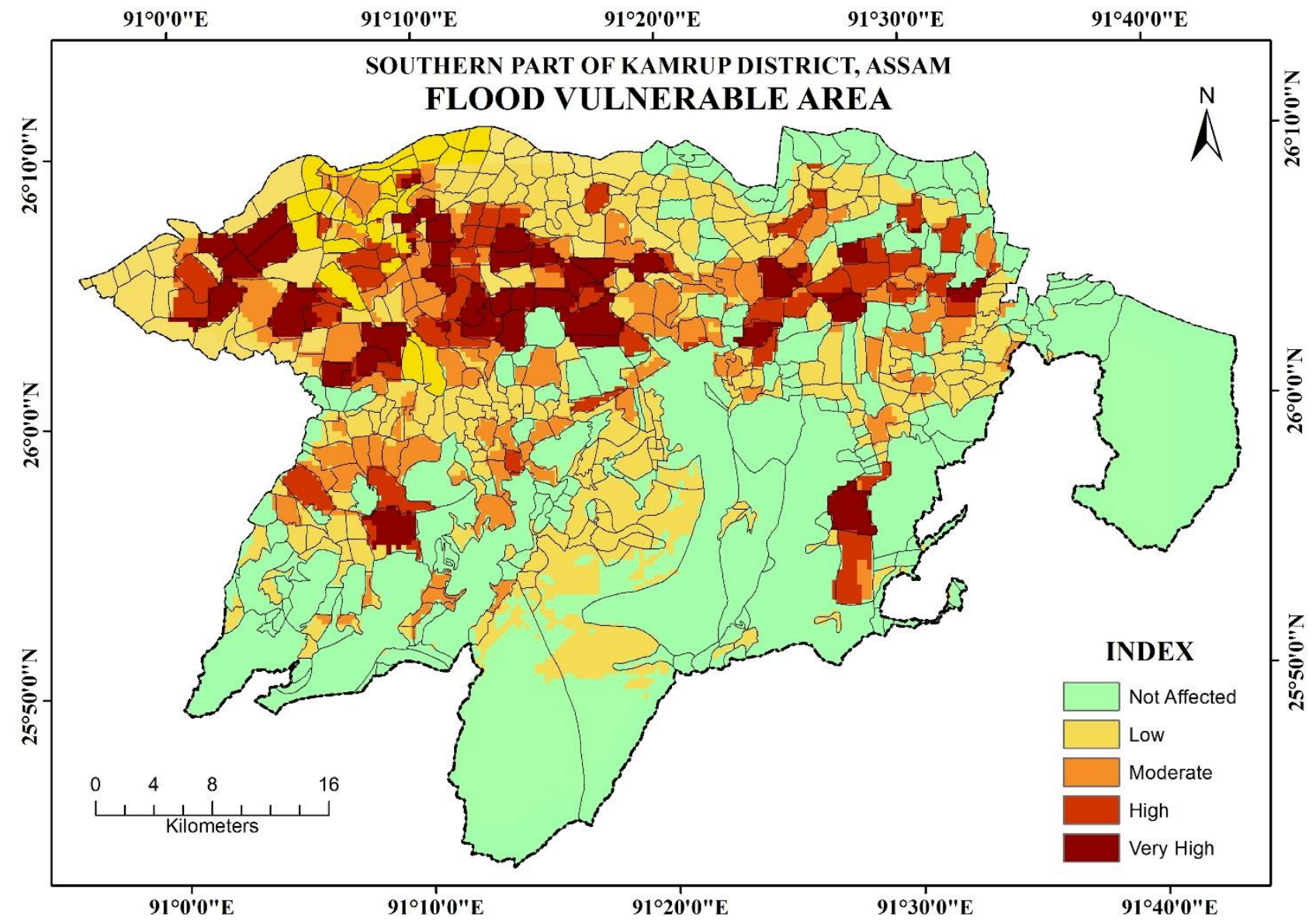

Figure 4: Flood Vulnerable Area

Source: Prepared by the Authors' based on the Socio-Economic Data (Ministry of Home Affairs, 2011) of Village and Ward Level and Flood Hazard Zones

\begin{tabular}{|c|c|c|c|c|c|}
\hline $\begin{array}{c}\text { VULNERABILITY } \\
\text { ASSESSMINT }\end{array}$ & $\begin{array}{c}\text { VULNERABLE } \\
\text { HOUSEHOLDS }\end{array}$ & $\begin{array}{c}\text { VULNERABLE } \\
\text { POPULATION }\end{array}$ & $\begin{array}{c}\text { VULNERABLE } \\
\text { FEMALE POPULATION }\end{array}$ & $\begin{array}{c}\text { VULNERABLE } \\
\text { CHILDREN }\end{array}$ & $\begin{array}{c}\text { VUNERABLE } \\
\text { MAIN } \\
\text { WORKBRS }\end{array}$ \\
\hline VERY HIGH & 32169 & 168283 & 83404 & 29697 & 94002 \\
\hline HIGH & 19814 & 100489 & 47735 & 14450 & 49252 \\
\hline MODERATE & 18432 & 96523 & 38654 & 9643 & 28765 \\
\hline LOW & 22654 & 187643 & 55326 & 18652 & 52814 \\
\hline TOTAL & $\mathbf{9 3 0 6 9}$ & $\mathbf{5 5 2 9 3 8}$ & $\mathbf{2 2 5 1 1 9}$ & $\mathbf{7 2 4 4 2}$ & $\mathbf{2 2 4 8 3 3}$ \\
\hline
\end{tabular}

Table 5: A Vulnerability Assessment of the Villages of the Study Area Source: Socio-Economic Data, Ministry of Home Affairs, 2011 of Village and Ward Level and Flood Hazard Zones

Flood vulnerable areas were categorised into the following types:

\section{Very Highly Vulnerable Area}

As illustrated in Table 5, thirty-seven villages that are very highly vulnerable to flood are prone to flood due to the very gentle slope and low elevation. This area mostly comprises of the active flood occurrence area. Out of these 37 villages, 34.6 per cent of households are at very high risk of flood. The percentage of the exposed population, female population, children and primary workers are at very high risk comprising $30.43,37.05,40.9$ and 41.8 , respectively. These areas are mostly on the southern part of the embankment of the river Brahmaputra and as such the free flow of flood water is obstructed. The close proximity of these villages to the river Brahmaputra, river Kulsi and river Singra is another major factor of flood. 


\section{Highly Vulnerable}

It is seen in Table 5 that 37 villages are highly vulnerable to flood hazard. These areas also comprise of the active flood occurrence area. The close proximity of the rivers and heavy rainfall coupled with low slope contributes to flood here. However, the elevation is slightly higher than the very highly vulnerable area. It is found that 21.3 per cent of households, 18.2 per cent of the population, 21.2 per cent of females and 19.9 per cent of children and 21.9 per cent of primary workers are at high risk of flood hazard. The connecting roads and hospitals need to be improved in the area to reduce the magnitude of vulnerability.

\section{Moderately Vulnerable}

This area is moderately on higher ground and the slope also differs from place to place. Towards the extreme north and north west side, the elevation is low but in the western part the elevation is moderately high. Besides the orographic situation of the area, the extensive deforestation of the forest area in the region also contributes to flood in this area. It is observed that 19.8 per cent, 17.5 per cent, 17.2 per cent, 13.31 and 12.8 per cent of households, population, females, children and working population are at moderate flood risk zone respectively.

\section{Low}

This area comprises of almost the entire district except the hilly area in the south and the east. The area is occasionally flooded because of heavy rainfall. As shown in the Table 5, 24.34 per cent households, 33.9 per cent of the population, 24.6 per cent female, 25.7 per cent children, and 23.5 per cent of the working population are at low-risk zone accordingly. The problem of excessive deforestation and terrace cultivation in the upper reaches of the river Kulsi, river Boko and river Singra in Meghalaya is the main factor of the flood.

The people in the area are fundamentally involved in agricultural activities, animal husbandry and fishing and they belong to diverse ethnicity and socio-economic classes. It is very challenging for these villages' farmers to survive with the flood hazards of different intensities from the river Brahmaputra's southern tributaries. The stagnant water causes difficulties in timely plantlet of crops and also spoils the standing crops. Animal husbandry also bears the impact of flood hazard.

\section{Conclusion}

Flood has been a chronic predicament in the southern part of Kamrup district and as a result of which noticeable alterations are seen in all phases of socio-economic activity. The area is recurrently affected by floods due to excessive discharge in the river Brahmaputra and the south bank tributaries. The foremost causes of floods here are the predominant and abundant rainfall in the catchment areas and insufficient capacity of the rivers Brahmaputra, Kulsi, Boko, Singra, Singhua river channels and the numerous prominent tributaries to hold the flood flow within the river banks. Flood has destroyed infrastructure and crops and has also deposited unfertile sand on the farmlands rendering them unfit for agricultural productivity. All of these have affected the people and livelihood of the communities to a considerable extent. In this study, an attempt has been made to represent the heterogeneity of different environmental and socio-economic aspects instrumental in flooding hazard. In this regard, a comprehensive analysis of the area susceptible to flood hazard is undertaken employing selection of three categories of flood-affected villages. A total number of twenty-two villages were selected and a base formed through stratified random sampling method. Besides garnering the details of the affected households' socio-economic characteristics and the loss sustained by the villagers, the surveyed data also monitored the existing mitigation and management strategies of the Government and other agencies. The indigenous methods of adjustment to floods like building the houses with low-cost materials, boats, raised platforms for storage of essential materials inside the houses, raised plinths of houses, building makeshift houses for shelter of human and animals over the embankment, raised hand pumps and wells were witnessed in the area. Thus, recurrent flood hazard has 
impacted the socio-economic conditions, domestic animals, dwellings, transportation, communication, well-being and sanitation, drinking water quality and educational activity, to name a few. Besides, out-migration of a segment of indigenous inhabitants and loss of occupation is a significant problem. Therefore, we can underline the significance of following a supervising system grounded on local knowledge, as a comprehensive, adaptive body of organisation to plan and manage flood vulnerability. The objective is to develop a community-based adaptation plan to formulate a micro-level disaster reduction plan. Afforestation programmes in the upper reach of the river basins will be very beneficial. Proper road connectivity and public health centres identifying higher ground for people's shelter and livestock are essential.

\section{References}

Assam State Disaster Management Authority. (n.d.) Hazard and vulnerability profile.

http://sdmassam.nic.in/hazardous.html

Birkmann, J. (2006). Measuring Vulnerability to Promote Disaster-Resilient Societies:

Conceptual Frameworks and Definitions. In J. Birkmann (Ed.), In Measuring

Vulnerability to Natural Hazards: Towards Disaster Resilient Societies (pp. 9-54).

United Nations University Press.

https://collections.unu.edu/eserv/UNU:2545/p df9789280811353.pdf\#page $=36$

Das, I. (2020). Geomorphic Hazards and Management in the Southern part of Kamrup District, Assam [Doctoral dissertation, Gauhati University]. Shodhganga: a reservoir of Indian theses@ @INFLIBNET.

http://hdl.handle.net/10603/267679

Department of Water Resources, Government of Assam, India. (n.d.). Flood \& Erosion Problems.

https://waterresources.assam.gov.in/portlets/fl ood-erosion-problems

Dhar, O.N \& Nandargi, S. (2004). Floods in North Indian River System. In K. S. Valdiya (Ed.),
In coping with natural hazards: Indian context (pp. 104-123). Orient Longman.

Goswami, D. C. (1985). Brahmaputra River, Assam, India: Physiography, Basin Denudation, and Channel Aggradation, Water Resources Research, 21(7), 959-978.

https://doi.org/10.1029/wr021i007p00959

Hazarika, P. (2016). Flow variability channel changes and associated hazards of Noa Mangaldoi river system, Assam [Doctoral dissertation, Gauhati University]. Shodhganga: a reservoir of Indian theses @ INFLIBNET. http://hdl.handle.net/10603/184028

Ministry of Home Affairs, Office of the Registrar General \& Census Commissioner, India.

(2011). District Census Handbook.

https://censusindia.gov.in/2011census/dchb/D CHB.html

Mirza, M. M. Q., Warrick, R. A., Ericksen, N. J., \& Kenny, G. J. (2001). Are floods getting worse in the Ganges, Brahmaputra and Meghna basins? Environmental Hazards, 3(2), 37-48. https://doi.org/10.3763/ehaz.2001.0305

MODIS Near Real-Time Global Flood Mapping Project. (2017). National Aeronautics and Space Administration.

http://oas.gsfc.nasa.gov/floodmap/

Morrow, B.H. (2008). Community resilience: $A$ social justice perspective. Community \&

Regional Initiative, Report Number 4. doi: 10.13140/RG.2.1.1278.9604

Sarma, J. N. (2005). Fluvial process and morphology of the Brahmaputra River in Assam, India. Geomorphology, 70(3-4), 226-256. https://doi.org/10.1016/j.geomorph.2005.02.0 07

Schmidtlein, M. C., Deutsch, R. C., Piegorsch, W. W., \& Cutter, S. L. (2008). A Sensitivity Analysis of the Social Vulnerability Index. Risk Analysis, 28(4), 1099-1114. https://doi.org/10.1111/j.1539-

6924.2008.01072.x

Sharma, SVSP., Srinivasa, R. G., Bhat, C.M., Manjushree, P. \& Bhanumurthy, V. (2012). g. 
Bulletin of the National Natural Resources

Management System. 87-91.

https://www.researchgate.net/publication/260

085195

Singh, O., \& Kumar, M. (2017). Flood occurrences, damages, and management challenges in India: a geographical perspective. Arabian Journal of Geosciences, 10(5). https://doi.org/10.1007/s12517-017-2895-2

\section{Conflict of Interest Statement}

We, the authors of the manuscript titled, Impact of Flood on the Socio-Economic Conditions in the Southern Part of Kamrup District, Assam hereby, declare that there is no conflict of interest related to the publication of the article.

\section{Acknowledgements}

We are profoundly grateful to the anonymous reviewers for their valuable recommendations. Equally, we are humbled by the efforts of all the village headmen of the entire study area and the local people for cooperating with us during the field survey.

\section{Author Contribution Statement}

While conducting the research work and preparing the particular manuscript titled Impact of Flood on the Socio-Economic Conditions in the Southern Part of Kamrup District, Assam, several components were contributed by both the authors as follows:

Dr Indira Das (Corresponding Author): Conducting empirical research, searching the literature and other resources, usage of software, validation of data, presentation of maps using GIS software, presentation of data through tables and figures and writing the original draft.

Professor Sujit Deka: Conceptualisation, methodology, curation and critical analysis of data, editing, reviewing, guidance and administration of the research work. 